\title{
JOHN, THE TALKING BABY OF LUKE 1:64
}

\author{
A D A M S A B I R
}

\section{ABSTRACT}

The aim of this article is to review the age-old assumption of who may be the object of the miraculous speech in Lk 1:64, without eliminating the traditional interpretation of Zachary as both loosing and receiving back his speech in conjunction with the events surrounding the birth of John. The thesis of the article is that the orator of Lk 1:64 is most probably the newborn baby John. The argument is a cumulative one and builds upon observations of grammatical, contextual and genre-specific nature. The last point is underscored by incorporating 2 (Slavonic) Enoch into the discussion.

\section{Key words}

Birth narrative miracles; John the Baptist; Talking babies; Narrative accounts; Zachary; Melchisedech; Miracles; Book of Enoch; Gospel of Luke

DOI: $10.14712 / 23363398.2019 .7$

$\mathrm{I}_{\mathrm{n}}$ Luke 1:64 the Gospel writer relates a peculiar incident taking place within the birth narrative of John the Baptist. Since John's father Zachariah had lost his speech earlier in the account, many commentators have been eager to interpret this verse as the moment where Zachariah's confirmation of John as the child's name is rewarded with the restoration of his speech. ${ }^{1}$ The parallel between the loss of speech

1 A variety of scholars have reached the same conclusion; see J. B. Green, The Gospel of Luke (Grand Rapids, MI: W.B. Eerdmans Pub. Co., 1997), 110; D. L. Bock, Luke (Downers Grove, IL: InterVarsity Press, 1994), 48-53; C. F. Evans, Saint Luke (London: SCM Press, 1990), 179-180; F. Bovon, Luke 1: A Commentary on the Gospel of Luke 1:1-9:50 (Minneapolis: Fortress Press, 2002), 70-71; E. Schweizer, The Good News 
and its restoration seems to be enough to motivate a link between these passages. However, Zachariah's restored speech could just as well be seen in verse 67 of the same chapter. Logically speaking, either both passages refer to the restoration of Zachariah's speech or merely one of them. The question the interpreter is faced with in the first alternative is what would motivate the Gospel writer to restate in two rather closely occurring passages that Zachariah once again was able to speak. If we pose the question of when Zachariah's speech was restored instead, the answer would be either in verse 64 or in verse 67 . However, does the text allow another possible interpretation of Luke 1:64 that would make sense in the closer context without necessarily challenging the traditional interpretation of Zachariah, whose speech had been restored at the moment John the Baptist is named?

In this paper, I investigate the possibility of interpreting verse 64 to mean that the speaker is none other than the infant John the Baptist himself. The discussion in this paper is divided into five parts. First, it will be argued that the grammatical structure does not exclude this possibility (negative argument); second, the context would be argued to suggest that this is the preferable interpretation (positive argument); third, it will be illustrated how verse 67 accounts for the traditional understanding; fourth, parallel mythological traditions of speaking babies, will be shown to account for a cultural possibility of such a thesis (without thereby necessitating Luke to be influenced by such accounts); and fifth, this new interpretation has philosophical implications, which will be briefly discussed.

\section{The Grammatical Possibility}

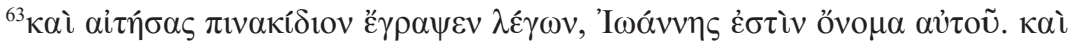

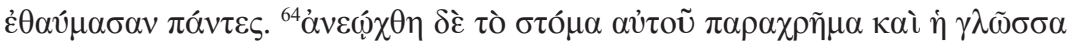

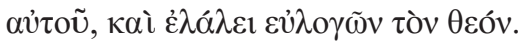

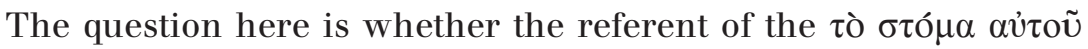
could be only Zachariah, or whether there is also another possibility. Luke does not give us a name but only a masculine pronoun. In the

According to Luke (London: SPCK, 1984), 37-39; W. Wiefel, Das Evangelium nach Lukas, (Berlin: Evangeliesche Verlagsanstalt, 1988), 60-61; R. B. Vinson, Luke (Macon, GA: Smyth \& Helwys Pub., 2009), 46-47. 
preceding context, it has two possible referent points. If it does not refer to Zachariah, it refers to John. The genitive $\alpha$ v่toũ certainly identifies that the mouth opened for the speech is proper to the one speaking. On the other hand, the passive aorist $\alpha v \varepsilon \omega \chi \emptyset \eta$ suggests that this opening of the mouth is miraculous. Rather than the speaker opening his mouth to speak, his mouth is opened and his tongue is loosed. This would imply that the speaker needed to have his mouth opened, most probably either because the speaker was unable to speak or not confident enough to do it.

God is most probably the one opening the mouth, and he is also the object for the subsequent eulogy. Hence, whoever the person whose mouth is opened and whose tongue loosened is and whatever reason stands behind it, the one performing this action is none other than God. Therefore, the event in this account is a miraculous one in the sense that it involves direct Divine intervention. The one whose

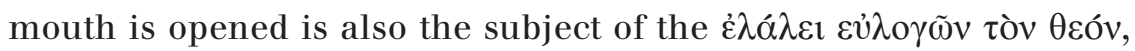
a eulogy with a content not further elaborated in the text; therefore, there are no further clues for the identity of the one giving the praise. Certainly, the $\alpha \dot{\tau} \tau o \tilde{v}$ could have its referent either in the preceding $\tau \tilde{\omega}$ $\pi \alpha \tau \rho \grave{~}$ of verse 62 , and hence, may refer to Zachariah, the father of the child. A second possibility is that $\tau \tilde{\varphi} \pi \alpha \tau \rho \grave{\imath}$ could refer to the $\alpha \dot{v} \tau o \tilde{v}$ of

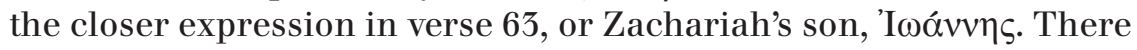
does not seem to be any immediate reason for preferring one referent above the other. Both a speech-deprived adult and a babe at his name giving could be a possible candidate for a miraculous speech. Certainly neither could be excluded on grammatical grounds. The referent of $\alpha \dot{v} \tau o \tilde{v}$ is hence not determinable on face value since both John and Zachariah would match the criteria of being unable to speak. Yet, equally true is the statement that none of the candidates is excluded by the description. But even though the referent of the aư $\tau$ ṽ in verse 64 could not grammatically be limited to Zachariah, one cannot necessarily infer that the babe is the one delivering the eulogy. For our purposes, however, it is enough to determine that our further investigation is not halted by grammatical impossibilities. The quest for the referent and thus the speaker must hence proceed to the immediate context of the narrative. 


\section{The Reaction of the Onlookers within the Immediate Context}

The reaction of the witnesses to the event is certainly striking and worth noting for several important reasons. In the immediate context of the event, they are said to be astonished with what has happened:

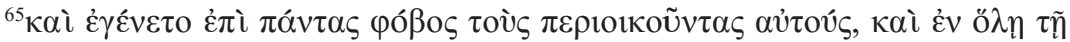

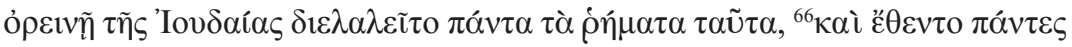

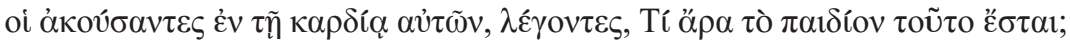

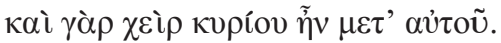

In verse 65 , we see that fear ( $\varphi \delta ́ \beta$ $\varsigma$ ) comes over all people present who witnessed the events. Fear occurs at least 20 times in Luke, more than in any other Gospel, and is often a reaction to something extraordinary happening. ${ }^{2}$ Most often, the object of fear is God, God's power or approaching judgment. In some cases Luke stresses what the object of fear should not be, namely men or the peaceful presence of Christ. ${ }^{3}$

Therefore, it is not altogether implausible that a miraculous event immediately triggered the fear. To hear Zachariah, the high priest of God, speak and praise God - despite the fact that he had lost his speech would not seem to be such a miraculous event to generate emotions of fear among those standing nearby. Indeed, for all they knew, Zachariah suddenly stopped speaking for unclear reasons, and his speaking again simply does not adequately explain the fear falling upon those present. Neither would the people present conclude from such an event that a miracle had occurred. However, for the babe to speak would

See Luke $1: 12,13,30,50,65,74 ; 2: 9-10 ; 4: 36 ; 5: 10,26 ; 7: 16 ; 8: 37,50 ; 12: 5,7 ; 18: 2,4$; $19: 21 ; 20: 19 ; 21: 26 ; 22: 2 ; 23: 4 ; 24: 36$.

3 For example, in Luke 8:50 Jesus encourages Jairus not to fear because of what has happened to his daughter. In 12:5 on the other hand, the particular emphasis is on

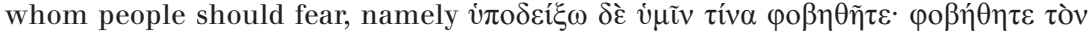

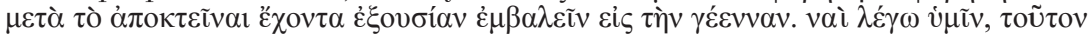
$\varphi \circ \beta \eta \dot{\theta} \theta \tau \varepsilon$. The fear of God seems most often to be associated with God's power. When the object seems to be to stress the potency of God's force or its approaching manifestation, fear seems to be encouraged $(12: 32 ; 21: 26)$. When the selfsame power is manifested or could be identified as such, fear seems to be the immediate reaction $(1: 12-13 ; 1: 30 ; 2: 9-10)$. The miraculous seems to be associated with divine power and sparks fear $(4: 36 ; 5: 26 ; 7: 16)$. This was not a new concept with Luke: See the use of in Ex. 14:31; Is. 25:3; Jer. 5:22,24; 10:6-12; and the use of פחד to mark terror in face of God's judgements in 1 QS 10:34; 4:2, 94. It is worth noting that in Josephus Antiquities 1:113-114, Nimrod is described as aspiring to bring people from the fear of God by denegrading the power of God and creating greater dependence upon himself. 
obviously be an extraordinary miraculous sign. A child born to aging parents who under strange circumstances receives a name uncommon to the family does appear to be an odd event, but would not in of itself motivate fear as a talking babe would. The eulogy if attributed to the babe, on the other hand, would be precisely such a strange event for which those present could clearly identify the Divine at work. Such an event would be unexpected and extraordinary and, hence, would need no further evidence of being a strange occurrence than the immediate gut reaction.

The expression $\tau \grave{\alpha} \rho \dot{\rho} \mu \alpha \tau \alpha \tau \alpha \tilde{u} \tau \alpha$ has in its function an explanatory force. Something is broadcasted around Judea. However, whether $\tau \grave{\alpha}$ $\oint \eta \dot{\eta} \mu \tau \alpha \tau \alpha \tilde{v} \tau \alpha$ refers to the eulogy itself and/or the miraculous event is not grammatically certain. If it were the eulogy, then the broadcast would be motivated somehow by the content of the speech. In that case, the speech would have had to be of such an interest to be worth notice and spread. The argument that $\tau \grave{\alpha} \hat{\rho} \eta \mu \alpha \tau \alpha \tau \alpha \tilde{v} \tau \alpha$ refers to the fact that Zachariah's speech was restored seems weak because why would a subsequent rumour arise about a priest praising God? After all, if we assume that a miraculous event triggered the rumour, a priest who actually worships God does not seem to constitute such a miraculous event. However, a third possibility may better explain the subsequent events.

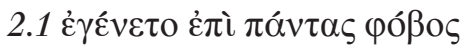

In the proximate context following the opening of the mouth and the eulogy, several things should be noticed: first, the onlookers' reactions and, second, Zachariah's reaction.

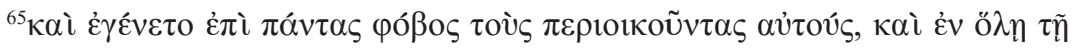

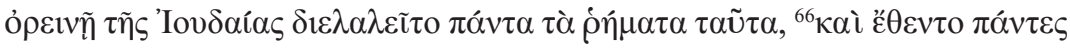

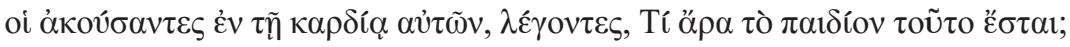

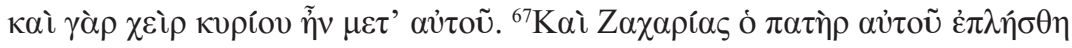

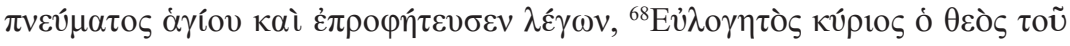

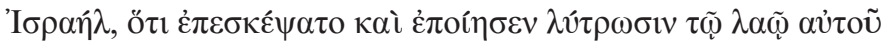

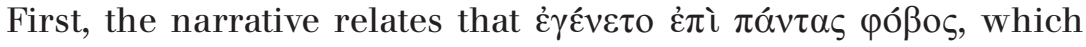
would be a natural reaction to any miraculous or unpredictable event. If we assume the narrative has a basic coherency, the event immediately preceding such a reaction must have been powerful enough to spark the reaction. However, a priest's sudden praise does not appear 
to be something that would trigger fear or even astonishment among onlookers. Indeed, for all they knew, Zachariah had been able to speak before - now he speaks again. Even assuming that something out of the ordinary had happened, neither such an event nor the choice of John as a name would seem to be powerful enough to explain a fearful reaction among the onlookers.

Indeed the word $\varphi o ́ \beta o \varsigma$, which is translated as the fearful reaction of the eye-witnesses, is not an altogether infrequent term in Luke. On the contrary, the term distinguishes the Lukan accounts in many ways, not only because of its frequency with about 20 occurrences, but also because of the context in which it occurs. With the possible exceptions of 1:74 and 8:50, póßo seems almost exclusively to be how Luke describes natural reactions to the miraculous. ${ }^{4}$ People react with fear, although they sometimes are urged not to fear or to redirect their fears. In Luke 7:16 póßo̧ is triggered among those who witnessed Jesus resurrecting the young man, and interestingly enough, is followed by the conclusion that a great prophet has arisen among the people. This incident illustrates that the miraculous fear-triggering event also could serve as a mark of identity once it became evident in whom the power of God resided. Even considering the first chapter alone, one can find

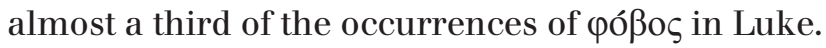

Upon closer look, the interplay between both Zachariah's and Mary's fearful reactions to a heavenly manifestation and the heavenly being's subsequent calming of them (1:13 and 1:30) reflects precisely the general use of fear in Luke. Hence, the mere use of the term in the context of the infancy narrative of John seems indeed to support that something undeniably miraculous took place. Since a priestly eulogy, even if preceded by an unexplainable silence, would not constitute an undeniable miracle, a better grammatical alternative to fit this forceful response would be a talking babe. Indeed a newborn opening his mouth in praise of the Divine would be clearly a more recognizable and undeniable miraculous event, better suited to explain the initial fearful reactions of those present. This does of course not negate that Zachariah's healing would not be miraculous. Here we are only dealing with what the onlookers could identify as such and what actually would trigger their reactions.

4 Miraculous here applies to any type of manifestation of Divine power, whether the manifestation of angels, healings, exorcisms, divine intervention, or natural miracles. For more examples, see note 3 . 
However, in this case, no heavenly body calms the witnesses' fears, unlike in the other accounts of the miraculous in the same chapter. ${ }^{5}$ Nevertheless, it would be a mistake to assume that every fearful reaction to any divine intervention would require calming. ${ }^{6}$ Rather, calm reassurance seems to be a question of whether or not the fear is motivated. In Luke 7:16 the reaction to a miracle seems to be that

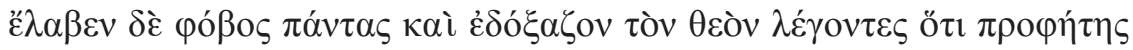

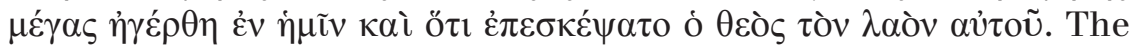
fear is not redirected or calmed within the narrative of this fearful response to the miraculous perhaps because the fearful reaction is indeed motivated and desirable, at least in the narrator's mind. Calming seems to be expected only when the reaction is not primarily intended. The reaction in Luke 1:65-66 parallels the one in Luke 7:16 in the sense that the fear leads to the intended conclusion that a prophet has arisen and God is visiting the people. Similarly, in the first chapter, the same reaction may be intended and, therefore, divine calming is not necessary. Rather, attention is given to the infant John and a conclusion is drawn regarding his future authority.

To recapitulate, the most plausible explanation for the magnitude of the witnesses' fearful reaction is that the newborn baby John, and not Zachariah, was the one praising God, which would constitute the identifiable miracle.

\section{$2.2 \tau \grave{\alpha} \dot{\rho} \eta \dot{\mu} \alpha \tau \alpha \tau \tilde{u} \tau \alpha$}

One more thing is worth noting: the subsequent spreading of the word. The $\tau \grave{\alpha} \hat{\rho} \eta \mu \alpha \tau \alpha \tau \alpha \tilde{u} \tau \alpha$ could possibly refer to what happened (the miraculous event in its entirety) or specifically to the content of the eulogy. Although we do not know the content of the eulogy, it does not seem that a priestly eulogy would receive such an extensive popular referral or notoriety as this notice seems to indicate, nor would the singular event of Zachariah's having his speech restored after losing it for a short time. On the other hand, the reaction would be completely in

5 The angelic being quickly calms Zachariah's and Mary's fears, triggered by the miraculous apparitions of 1:13 and 1:30. The pattern is repeated in 2:10, whereas in 5:10, Jesus calms Simon after the fishing miracle.

${ }_{6} \quad$ Reactions of fear in light of the miraculous that are not followed by a calming are also found in 4:36, 5:26 and 8:37. In contrast to 24:36., in which Jesus appears to his disciples and calms them, these passages leave witnesses entangled by fear. In 4:36 and $7: 16$, the onlookers draw conclusions about the authority of Jesus. 
line with what would be expected if indeed the story retold the miraculous event of a eulogising infant. Both the event and its contents would be the subject for fear, astonishment, and intensive rumours.

Something else that should be taken into account is that the words spoken, the event, or both left a lasting impact upon those present,

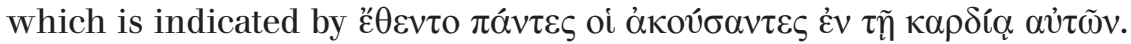
Even if the heart frequently appears in the language of the Gospel literature, only this passage in Luke uses the more precise expression of 'keeping in the heart'. Moreover, this expression occurs only in a few places in Luke, namely 1:66, 2:19 and 2:51. Could these other passages give us a hint about how to interpret 1:66? The immediate difference between the expressions in chapter two and in 1:66 is that, in the former, Mary is the one keeping the words in her heart, and Jesus is directly or immediately the source of the comments of the words kept. The context of $2: 51$ is the child Jesus and his speech in the temple, and 2:19 is the account of the testimony concerning the child.

Indeed, as described in the discussions above, both the words of or about baby John are plausible interpretations of $\tau \grave{\alpha} \rho \dot{\eta} \mu \alpha \tau \alpha \tau \alpha \tilde{v} \tau \alpha$, although the former is preferred. Even if the events in Jesus's childhood perhaps were not miraculous, this account of the infant John can be interpreted as a miraculous narration for two reasons. First, although we can see that the account of Jesus in 2:19 and Simeon's statements share some similarities with John in 1:65 and Zachariah's speech (both infants receive a weighty testimony from well-known characters), Zachariah's predictions are about God and not the child John. In other words, Simeon says something about the future of the child (Jesus), but Zachariah praises God without mentioning the child (John). Therefore, to say that those present understood Zachariah's eulogy to concern John's future would need to be explained by its proponents. If indeed the onlookers' reaction happened with regard to Zachariah speaking rather than to what happens with his son, and furthermore, if what Zachariah eulogizes in 1:68-79 does not concern John, why would the onlookers' statements refer to the child rather than the father? Such an explanation has not been given in any commentary up to date. But as will be argued in the following, the reason for why the onlookers conclude something about the future greatness of the child is most easily explained by that it is the babe that is the object of the miracle in 1:64. 


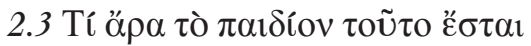

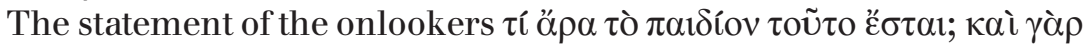

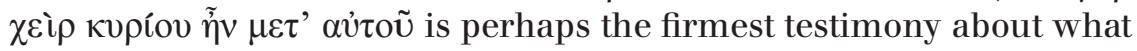
happens at the story level. The words are those of the people present whose attention is directed not towards Zachariah - which would be expected if he were the main object of the miracle or the one perform-

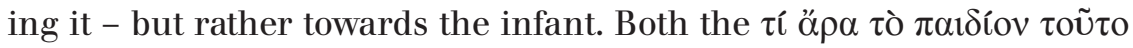

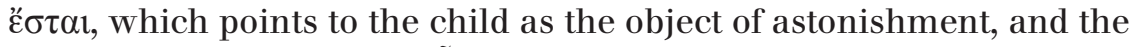

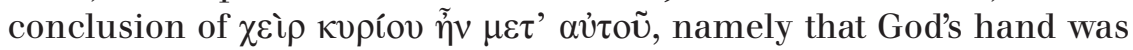
with this child, do not seem to give the required attention to Zachariah that interpretive tradition requires. The onlookers do not respond to anything that has happened to Zachariah or by Zachariah, nor do they seem to conclude from the father's eulogy that God's hand was with the child and that something special would come from him rather than the father.

The most plausible explanation seems to be that the public responded to something extraordinary that happened involving the child, and I suggest this response was the so-called natural reaction to a eulogy from the child and not the father. Such an interpretation would explain why the public reacted as they did, why they kept these words in their hearts, why the words were subsequently spread, and why they concluded that God's hand indeed was with this child and that something astonishing would come from him. The traditional explanation - Zachariah, as a eulogising priest and the immediate source of the public reaction - does not seem to account for all these aspects and simply fails to explain why the child receives attention in immediate conjuction to verse 64 and why conclusions are drawn about him. In addition, the traditional view of verse 64 makes it puzzling to explain why the public would keep a priestly eulogy in their hearts and spread such a rumour across the land because a priest would rather be assumed to offer praises to God. The conclusions therefore follows, that the object of the miracle in verse 64, was John and not his father Zachariah. Does such a conclusion negate the traditional belief in that Zachariah had his speech restored at the event of naming of John the Baptist? In the following lines it will be argued that verse 67 is the proper loci encapsulating the restoration of Zachariah's speech. 


\section{When was Zachariah's Speech Restored?}

Certainly, an element of the story seems already to establish John's importance - the age of his parents at his birth. This element has connotations with other special children who were born late in their parents' lives, such as Isaac and Samson. However, this notion should not be overplayed because the characters in the story give no attention to these parallels, and moreover, to see John as another Isaac or Samson would require viewing Zachariah as another Abraham, something that is not indicated in the story or in his being punished for lack of belief in 1.20. However, if verse 64 is attributed to the infant John, would it challenge the traditional notion that Zachariah received back his speech and is the originator of the benedictions of vv. 68-79? By no means. In the preamble to this article, we posed the question when Zachariah's speech was restored. The answer seems to be found in verses 67 and 68 which state:

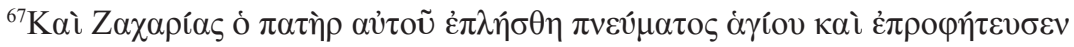

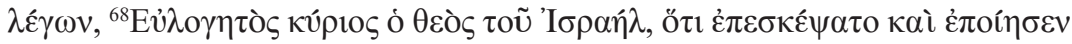

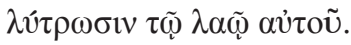

Hence, in this instance, it can be said that Zachariah is certainly the speaker. Worth noting is the expression that he became $\dot{\varepsilon} \pi \lambda \eta \sigma \theta \eta$

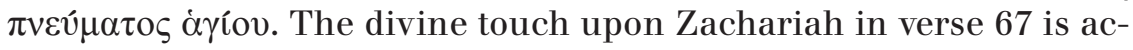
tually the moment when his speech is miraculously restored, rather than in the earlier instance $(1: 64)$. There is no reason to propose that Zachariah would have his speech miraculously restored twice or be 'filled with' $\dot{\varepsilon} \pi \lambda \eta \dot{\eta} \theta \eta \pi v \varepsilon v \dot{\mu} \mu \tau \sigma \varsigma \dot{\alpha} \gamma$ íov a second time after the miracle of having his tongue already loosed. Here it seems the traditional account of the miraculous unbinding of Zachariah's tongue is vindicated, and forcing it earlier in the narrative (1:64) is therefore unnecessary.

The context of Zachariah's praise is also interesting. He prophesies about God having visited and redeemed his people and raised a horn of salvation (v.69), and he prophecies directly about the child John (v.76). However, this statement follows only after the sequence in the narrative in which the onlookers have drawn their conclusions, and it would be anachronistic to conclude that Zachariah's prophecy 
is the source for the witnesses' earlier reaction to the child's future importance. ${ }^{7}$

\section{Early Jewish Traditions about Speaking Baby Prophets}

The notion of speaking infants is not unprecedented in Jewish tradition. ${ }^{8}$ When the Gospel of Luke was written, several such traditions were in existence. Luke does not need to be influenced by such traditions and we do not here argue any literary dependency on the parallel

7 A challenge to this conclusion would be proof that Zachariah's prophecy actually preceded the onlookers' reaction. This proof would mean that this section should follow v. 64, or conversely that verses 65 and 66 should sequentially follow Zachariah's prophecy, which should not be excluded, but would nevertheless require firm argumentation. Such a move also would require that verse 80 sequentially remain in its current position.

8 In the following, references are made to 1 Enoch, 2 (Slavonic) Enoch and to the Exaltation of Melchizedek. The latter is usually believed to be a part of the longer ending of 2 (Slavonic) Enoch, and therefore, both are either attributed to a Jewish author from first-century Alexandria or are considered latter works from the third century. The two incomplete manuscripts from the 13th century have been the subject of intense debates. However, this article's working premise is that both accounts reflect earlier traditions, whether they are considered conjointly or not. More detailed discussions may be found in J. T. Milik, ed., The Books of Enoch (Oxford: Clarendon, 1976) and G. W. E. Nickelsburg, Jewish Literature Between the Bible and the Mishnah (London: SCM, 1981). For a review of some major questions regarding 2 (Slavonic) Enoch, refer especially to pp. 316-317 in J. H. Charlesworth, 'The SNTS Pseudepigrapha Seminars at Tubingen and Paris on the Books of Enoch', New Testament Studies 25 (1979): 315- 323. For a general introduction to the relationship between Enochic and Lukan material, see S. Aalen, 'St. Luke's Gospel and the last chapters of I Enoch', NTS 13 (1966): 1-13. For practical reasons, the account from the Exaltation of Melchizedek is referred to here as a separate account. However, the dating of this work is immediately connected to discussions about whether it is part of 2 (Slavonic) Enoch. The first critical edition of 2 Enoch argued against this proposition; see A. Vaillant, Le Livre des Secrets d'Henoch, Texte Slave et Traduction Francaise (Paris: 1952), 3. For more recent debates concerning 2 (Slavonic) Enoch 71.1-73.9, see A. A. Orlov, 'Melchizedek legend of 2 (Slavonic) Enoch', Journal for the Study of Judaism 31 (2000): 23-38; 'On the polemical nature of 2 (Slavonic) Enoch: A reply to C. Böttrich, JSJ34 (2003): 274-304 and C. Böttrich, 'The Melchizedek story of 2 (Slavonic) Enoch: A reaction to A. Orlov', JSJ32 (2002): 445-470. Böttrich convincingly argued for the longer ending of 2 Enoch as more archaic, especially regarding observations about continued centralized sacrificial practices and in particular the 'cult-foundation festival' of 2 (Slavonic) Enoch 68:5-69:11. See C. Böttrich, 'Melchizedek story, 447-449, 451; Weltweisheit - Menscheitsethik - Urkult, Studien zum slavischen Henochbuch, WUNT 2/50 (Tubingen: Mohr Siebeck, 1992), 781; Das slavische Henochbuch (Gutersloh: Gutersloher Verlagshaus, 1995). The force of Böttrich's argument is that 2 (Slavonic) Enoch not only precedes $70 \mathrm{AD}$, but also is highly unlikely to be a latter Christian fabrication. The fear that the birth of Melchizedek would disturbingly parallel the Jesus accounts lacks substance. For further investigation, consult the most recently published synopsis of existing textual evidences for 2 Enoch by G. Macaskill, The Slavonic Texts of 2 Enoch (Leiden: Brill, 2003). 
accounts. Rather, their existence merely proves that the interpretation proposed in this paper is in line with what already was culturally tangible. Although the existence of these stories is not a definitive proof that John's birth narrative should be read in similar terms, it does place the burden of proof on those critics who would suggest that talking infants are an absurd suggestion of a miracle and an unlikely interpretation of the events.

Indeed, there are several early Christian accounts of the miracles and deeds of Jesus as a child, such as the Infancy Gospel of Thomas. ${ }^{9}$ Many of these and other traditions were later edited into the Quran. However, these miraculous events are mainly ascribed to Jesus, and to my knowledge there is only one parallel account of a miraculous cradle speech of John the Baptist. ${ }^{10}$

\subsection{Noah's Birth}

There are, however, Jewish precedents even before these narratives. The first one is the account of Noah's birth in 1 Enoch, which most scholars believe to be a first-century composition. This post-exilic apocrypha records that Methuselah took a wife to his son Lamech.

${ }^{9}$ For an overview of the various infancy narratives, see J. K. Elliott, A Synopsis of the Apocryphal Nativity and Infancy Narratives (Leiden: Brill, 2006); S. Davies and A. E. Siecienski, The Infancy Gospels of Jesus: Apocryphal Tales from the Childhoods of Mary and Jesus - Annotated \& Explained (Woodstock: SkyLight Paths, 2009).

10 In The Arabic Infancy Gospel, 1, Jesus announces his divinity from the cradle: 'Jesus spoke, and, indeed, when He was lying in His cradle said to Mary His Mother: I am Jesus, the Son of God, the Logos, whom though hast brought forth, as the Angel Gabriel announced to thee; and my Father has sent me for the salvation of the world'. The tradition of a speaking baby Jesus is recycled in the Qu'ran, first in Sura 3.46, which referring to Issa (Islamic Jesus) says that 'He shall preach to men in his cradle and in the prime of manhood, and shall lead a righteous life'. The content of this cradle speech is also recorded in Sura 19.28-34 in which the spoken message almost seems deliberately to be the opposite of the one in The Arabic Infancy Gospel:

'O sister of Aaron! Thy father was not a wicked man nor was thy mother a harlot'. Then she pointed to him. They said: 'How can we talk to one who is a child in the cradle?' He said: 'I am indeed a servant of Allah. He has given me the Book and has made me a prophet. And has made me blessed wheresoever I may be and has enjoined upon me prayer and almsgiving so long as I remain alive. And (has made me) dutiful toward her who bore me, and hath not made me arrogant, unblest. Peace on me the day I was born, and the day I die, and the day I shall be raised alive!' Such was Jesus, son of Mary: (this is) a statement of the truth concerning which they doubt. A similar parallel is found in The Arabic Infancy Narrative, 36 and Suras 3.49 and 5.110 concerning giving life to clay birds. Both texts appear rather late in history, the earlier Arabic Infancy Gospel is dated somewhere between the fifth and sixth centuries A.D., if it is taken to build upon a Syriac archetype; see J. K. Elliott, A Synopsis of the Apocryphal Nativity and Infancy Narratives (Leiden: Brill, 2006), 100-107. 
Noah, the son born of this union, is described in 106:2b-3 to be both strange in appearance and conduct: ${ }^{11}$

And his body was white as snow and red as a rose; the hair of his head as white as wool and his demdema beautiful; and as for his eyes when he opened them the whole house glowed like the sun - (rather) the whole house glowed even more exceedingly. And when he arose from the hands of the midwife, he opened his mouth and spoke to the Lord with righteousness. ${ }^{12}$

Although nothing in the account of the birth of John the Baptist suggests that he had a striking appearance, this tradition illustrates that at least to some contemporary minds, talking newborns were not an unprecedented phenomena and were a theme used to underline the importance of the hero character. ${ }^{13}$ In conjunction with this tradition, several things should be noted in the story of the speaking baby Noah: 1) his father's reaction, 2) the content of Noah's miraculous speech and 3) how Enoch interprets this sign.

First, Lamech's immediate reaction when his luminous son 'spoke to the Lord' is the one of fright and flight (1 Enoch 106:4). He retells what has happened to his father Methuselah, who in turn is petitioned to learn the truth of this matter from Enoch. In Methuselah's report to Enoch the luminous appearance of baby Noah is emphasised, and to this is once again added that he 'rose up in the hands of the midwife, he opened his mouth and blessed the Lord of heaven' (106:11). In the story, Lamech fears that Noah is a descendant of the fallen angels:

11 Unless otherwise noted, all quotes from the Enochic literature are found in F. I. Andersen '2 (Slavonic Apocalypse of) Enoch,' The Old Testament Pseudepigrapha (ed. J. H. Charlesworth; New York: Doubleday, 1985), i.91-221. For issues surrounding dating, consult pp. 6-7 in the same.

12 Some variant translations read 'to the Lord of righteousness' and others, 'he blessed the Lord'. For additional references, consult Andersen, '2 (Slavonic Apocalypse of) Enoch,' 1.139 .

13 The importance of John the Baptist in the Gospel of Luke is underscored in several ways. That John is in no way a lesser prophet than any other in Israel's history is perhaps most clear in Luke 7.28, which declares John the Baptist the greatest of the prophets born amongst women. See B. Viviano, 'The least in the kingdom: Matthew 11:11; Its parallel in Luke 7:28 (Q), and Daniel 4:14', Catholic Biblical Quarterly 62, 1 (2000): 41-54. 
Then his father Lamech became afraid and fled, and he did not believe that he (the child) was of him but of the image of the angels of heaven. And behold, I have come to you in order that you may make me know the real truth (106:12a).

Enoch reaffirms both that Noah is Lamech's son and the tradition of fallen angels' giving birth to physical giants whose evils merit the subsequent destruction of the earth. The one who will be saved together with his three sons is Noah:

There shall be a great destruction upon the earth; and there shall be a deluge and a great destruction for one year. And this son who has been born unto you shall be left upon the earth; and his three sons shall be saved when they who are upon the earth are dead. ${ }^{14}$

Besides the obvious parallels between these Enochic traditions and John the Baptist, such as foreseeing an approaching punishment, the most striking similarities of these birth stories are a) the miraculous speech of the child, b) in the form of a eulogy towards God, c) which triggers a fearful reaction, and d) concludes with a prediction about the child's eschatological importance.

\subsection{Melchizedek's Birth}

The second tradition is found in the so-called Exaltation of Melchizedek from the first century BC. ${ }^{15}$ In this document, the fabulous account of the birth of Melchizedek supposedly precedes the deluge by 40 years. ${ }^{16}$ Nir is Noah's brother and the husband of the aged Sopanim. Not unlike Elizabeth in the Lukan account, Sopanim is of a mature age and barren when she becomes pregnant. Another similarity with the Lukan narratives is the appearance of the archangel Gabriel in this account. ${ }^{17}$ Sopanim also resembles Elizabeth in that she keeps herself away from the public during her pregnancy (2 Enoch 71:3), and Nir resembles Zachariah in that he has a priestly role because 'the Lord had

\footnotetext{
141 Enoch 106.15-16.

15 The Exaltation of Melchizedek belongs to the longer recension of 2 (Slavonic) Enoch and consists of 71.1-73.9. See note 8 for additional details.

16 F. I. Andersen, '2 (Slavonic Apocalypse of) Enoch', The Old Testament Pseudepigrapha (ed. J. H. Charlesworth; New York: Doubleday, 1985 (1983)), 1.91-97.

17 Some believe this to be a later addition. See ibid., 1.206.
} 
appointed him to conduct the liturgy in front of the face of the people' (2 Enoch 71:2b).

Striking dissimilarities in the accounts can also be noted. Enoch emphasises that Nir had no relations with his wife during his priestly service and had no part in Melchizedek's miraculous conception (2 Enoch 71:2a). Also, Sopanim gives birth to the child Melchizedek only after her death (2 Enoch 71:9,17). While Noah and Nir supposedly are planning to bury her corpse in haste out of cognisance of the people, the account relates:

And a child came out from the dead Sopanim, and they saw the child sitting beside the dead Sopanim, and wiping his clothing. And Noe and Nir were very terrified with a great fear, because the child was fully developed physically, like a three-year-old. And he spoke with his lips, and he blessed the Lord. ${ }^{18}$

Like Noah, the newborn Melchizedek in this account opens his mouth for speech in the form of a eulogy towards God. As in the accounts of Noah and John the Baptist, the child's speech triggers immediate fear among those present, Nir and Noah. Nir inquires with the Lord about the child, and becomes aware of the child's priestly dignity and future salvation from the deluge (2 Enoch 71:26-29). Similar to the Lukan account, the story proceeds with a eulogy and prophecy from Nir about the child (2 Enoch 71:30-31), and as in the story of Noah's birth, this story includes a warning of impending doom (2 Enoch 71:26; 72:1). However, Melchizedek will be saved from the deluge - not on the ark, but by being transferred by the angel Michael to Eden from which he later will appear to re-establish the priesthood with a second Melchizedek called the great Igumen (2 Enoch 72:5-11). Therefore, all three accounts show similar patterns of speaking prophetic infants imbued with future historical importance.

To recapitulate, at the time the Lukan account was written, several traditions existed that attached miraculous 'from-the-crib-eulogies' to characters famous in the people's traditions. Whatever else the function of these narratives may have been, they seem at least partly to have emphasised the importance of the characters (eulogising infants) as chosen by God in a time of apostasy. The birth accounts of Samson,

182 (Slavonic) Enoch 71:17-18. 
Moses, Samuel, and Jesus also illustrate the importance of grounding a particular character's chosen-ness and significance from infancy. In the light of such traditions, accounts of talking babies seem to further emphasise the importance and role of the chosen character. In these three examples, several themes recur: a) the miraculous event surrounding the birth of a prophet, b) the speech of the prophetic child, c) the reactions of fear and astonishment, and d) the child's impending importance in an upcoming cataclysmic event. These recurring themes add plausibility to the earlier exegetical remarks upon the Lukan account's narrative of the miracle in 1.64. Therefore, the narrative about John the Baptist seems to illustrate the wide held belief of the importance and choosen-ness that this character enjoyed when the Gospel of Luke was composed and a possible reason for the respect he enjoyed during his ministry. Indeed, Jesus's remarks that John the Baptist is the greatest among the prophets and among those born by women (Luke 7.28) would not necessitate such an account but make it plausible in light of some of the traditions surrounding the miraculous birth of earlier prophets.

\section{Some Final Remarks}

What has hindered this interpretation from being advanced earlier? For one, studies of New Testament exegesis for much of the early modern period have sought to reconcile accounts of the miraculous in the Gospels to a post-enlightenment paradigm in which miracles are no longer taken for granted. Whether any historical examination of miracles is refuted or whether the miraculous is reinterpreted or denied altogether, these miraculous accounts are subject to intense debate. In such a climate, commentators on either side of the argument may not be eager to see more battlefields emerge from the texts. However, this article points out good reasons to accept that the birth of John - which already is described as the result of divine intervention - just may have an additional layer of the miraculous.

Discovery of such an additional miraculous element has some further implications. First, it emphasises the place and role of the miraculous in the Gospel of Luke. If anything, the narratives are more flavoured with this element than previously estimated. This stresses the need to discuss the gap between modern readers and ancient writers from the standpoint of what is incongruous in their world-views. In 
other words, in a closed and self-explanatory thought-world following modern assumptions of the noninterference of any extra natural force, the miraculous event is not seen to be possible and therefore is also overlooked in the claims of ancient texts. The latter, on the other hand, are often open to divine intervention. In the view of the ancient penmen, such interventions are not infrequently seen as a guarantee for the content of the message they tried to establish. Bridging this gap is necessary to come closer to the motives and beliefs of the ancient penmen. Second, the birth narrative of John the Baptist seems to underline his important role in early Christianity. To speak in infancy was a contemporary way to ascribe and emphasise the election and special role of a prophet in the approaching events of significant magnitude. By using this framework to portray John the Baptist, the writer prompts re-evaluation of John's importance and the possible traditions behind his contemporary popularity and following. In the Gospels, Jesus seems to emphasise the important role John the Baptist plays, and the narrators are eager to describe him as a prophet among the people, respected even among governmental authorities. Earlier accounts of chosen prophets are consistent with what is proposed in this article and could partially explain John the Baptist's contemporary popularity. In other words, John established his authority as the unique voice crying in the wilderness by already speaking in his infancy.

Långgatan 24 74742 Gimo Sweden E-mail:Bezuszko@gmail.com 